\title{
Scenarios of Urban Land Use Pattern: A Case Study of Raipur City, Chhattisgarh State, India
}

\author{
Rajib Jana ${ }^{1 *}$, Anil Kumar Sinha² \\ ${ }^{1}$ Research Scholar (Geography), Sant Gahira Guru Vishwavidyalaya Sarguja Ambikapur (Chhattisgarh State), India. ${ }^{2}$ Assistant Professor \\ (Geography), at present NSS Programme Co-ordinator, Sant Gahira Guru Vishwavidyalaya Sarguja Ambikapur (Chhattisgarh State), India.
}

\begin{abstract}
Land is the prime resource for human beings. Since the beginning of human existence of man has directed his activities with reference to earth resources. Urban land use is one of the most important components of the urban life support system, which have been over used and even abused over the centuries. A city is an outcome of physical growth process and reflects man's effort and achievements in shaping his environment during the entire period of its development. Quality of urban life and functional efficiency of a city is governed by proper disposition of activities expressed as urban land use. In respect to the urban morphological studies, the urban land use pattern are based on morphological structure, population density, land uses in various sectors, administrative set up etc. The Study area Raipur city is situated in the heart of Chhattisgarh state. This area is extended from 21 14' 14"N latitudes to 81 38' 5"E longitudes. The main objectives of the present study are to analysis the scenarios of urban land use pattern of Raipur city in 2011 with reference to past decades as well as proposed urban land use pattern. The present research paper has been based on both the primary data and secondary data which are acquired through field survey method and the Master Plan (2011) of Raipur city (town and country planning department, Raipur, Chhattisgarh State) respectively. Statistical analysis and cartographic techniques are use to represent the scenarios of urban land use pattern of Raipur city. The main findings of this research paper is that, the Raipur city are divided into 6 categories of urban land uses; Residential-56.3\%,Industrial-11.6\%,Commercial4.8\%,Public\&semi-public-12.1\%,Recreational - 2.7\% and Transportation- $13.5 \%$ which is different from past decades due to the rapid growth of urban population as well as immigration in Raipur city.
\end{abstract}

Keywords: Land Resource, Urban Land Use Pattern, Physical Growth Process, Rapid growth of urban population, Master Plan, Raipur City.

\section{INTRODUCTION}

The natural resource point of views, land is the prime resource for human beings. Since the beginning of human existence of man has directed his activities with reference to earth resource. Urban land use is one of the most important components of the urban life support system, which have been over used and even abused over the centuries $(1,2)$. A city is an outcome of physical growth process and reflects man's effort and achievements in shaping his environment during the entire period of its development. The shape, size and

*Address of Correspondence: Rajib Jana, Research Scholar (Geography), Sant Gahira Guru Vishwavidyalaya Sarguja Ambikapur (Chhattisgarh State), India. E-mail- rajibgeo1990@gmail.com (Received 03 October 2020; Revised 07 October 2020; Accepted 13 October 2020) 
direction of growth of a any city is the result of various forces - physical, economic and social which have played a significant role in its development (3-5). Quality of urban life and functional efficiency of a city is governed by proper disposition of activities expressed as urban land use. A detailed land use survey has been conducted in respect of developed area of the city within the planning area to understand and critically analysis functional relationship between various uses and to identify incompatible and inefficient land uses $(6,7)$. The city has witnessed its urban growth both in terms of time and space. Every city is unique in the respect of site and situation, geographical setting, historical growth and population characteristics. These factors collectively affect the shaping of existing urban land use pattern and its classification with particular reference to future growth and prosperity (8). The study shows that fundamental importance is also given to the existing urban land use pattern of fringe area. Population is increasing day by day, so resources are also finishing rapidly, for preventing these conditions the most geographers and research scholars are mainly focused on the scenarios of urban land use pattern $(9,10)$.

\section{STUDY AREA (Raipur City)}

Raipur city is located in the heart of Chhattisgarh state. Raipur is the premier city as well as the capital city of the Chhattisgarh state which is an important administrative, commercial, industrial and educational Centre. The established of Bhilai steel plant in close proximity has given a great impetus to its growth. Raipur city (21 14' $14 " \mathrm{~N}$ latitudes and 81 38' 5"E longitudes) is an important junction on the Mumbai-Kolkata trunk line of the south eastern Central railways and the premier node of the highways leading to Kolkata, Mumbai, Bilaspur and Vishakhapatnam, enjoy a Centre location in the Chhattisgarh sate. Total geographical area of Raipur city is $326 \mathrm{sq}$. $\mathrm{km}$. The site of Raipur city is a low ridge on the north-east of the river Kharun, a tributary of Shivnath River. Raipur city is situated in the central part of Chhattisgarh basin; certain geographical characteristics of the situation have made the city the biggest and most significant nodal point and capital of Chhattisgarh state.

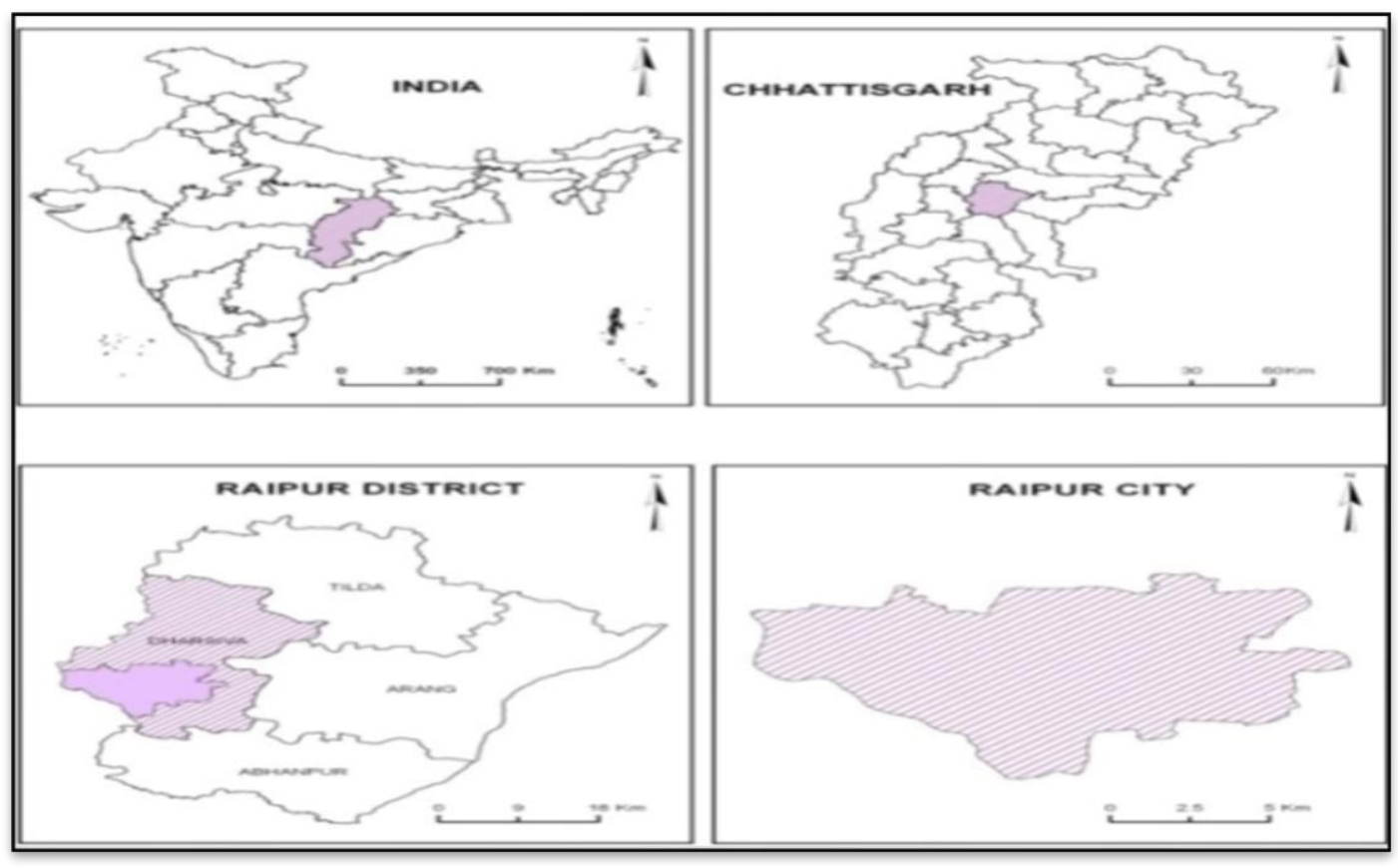

Figure 1: Location Map of Study Area (Raipur City) 
The natural slope of the land is towards north-Mahanadi is the primary river of the region. From geological point of view Most of the area is made up of purana rocks belonging to cuddapah system. Raipur city lies in the tropics, being about $250 \mathrm{~km}$. south of the topic of cancer of passing a tropical monsoon climate with a seasonal rhythm. The city experiences the climate of 'Aw' type of koppen, characterized by the hot summer, a pleasant cold winter with dryness except the monsoon season.

According to census 2011, the total population of Raipur city is $10,10,087$. The Urban agglomeration point of view, Raipur city comes under metropolitan region because the city having a population of more than 10 lakhs which is governed by municipal corporation. Raipur city holds 45th rank in India and 1st rank in Chhattisgarh state. The total metropolis area of Raipur city is $226 \mathrm{Sq}$. $\mathrm{Km}$.

\section{OBJECTIVES OF THE STUDY}

The key objectives of the present research paper are as follows

(1) To analysis the scenarios of urban land use pattern in Raipur city.

(2) To find out the effect of human on urban land use pattern in Raipur city.

(3) To analyze the problems and prospects of existing urban land use pattern in Raipur city.

\section{SOURCES OF DATA AND RESEARCH METHODOLOGY}

The present research paper has been based on both the primary data and secondary data which are acquired through field survey method and the Master Plan (Existing urban land use -2011and Proposed urban land use -2021) of Raipur city (town and country planning department, Raipur, Chhattisgarh State) respectively. The collected data had been processed and analyzed with the help of statistical techniques as well as cartographically represented by various tables, maps and diagrams for represent the scenarios of urban land use pattern of Raipur city.

\section{DISCUSSION AND MAIN FINDINGS}

\section{Urban land use pattern}

The urban land use pattern determined to a great extant the functional efficiency of a city. It is the used zones, which govern the transport network system for speedy movement of peoples and goods. In fact the policy and principles of planning have a great bearing on urban land use pattern of the city (11).

\section{Importance of urban land use pattern}

Urban land use explain the use of land devoted to various human activities, they study of an existing urban land use pattern of a city. The importance of urban land use pattern is as follows

(i) Land use is an important aspect of geographical studies particularly relevant to urban geography.

(ii) To establishment an economically prosperous of city.

(iii) To determine the optimum land utilization.

(iv) To maximize benefits in terms of inputs.

(v) To suggest profitable adjustment and changes according to the new.

\section{Consideration of urban land use pattern}

In general, the urban land use pattern has been evolved on the following consideration.

(i) Integration and continuous growth of important urban land use.

(ii) Mixed urban land use planning.

(iii) Inter-relationship of highest order activities with planning unit activities.

(iv) Physical, economic and emotional integration.

(v) Minimum dislocation of present urban land use pattern.

\section{Scenarios of Urban land use pattern in 2011 of Raipur city}

The land use of a city is classified on the basis of different work which is held on the land. The social and cultural structures also influence upon the land use pattern. The main indicators of urban land use pattern are that the economic activities, dynamic process, land value, urban renewal, social process and zoning as well as planning. Urban Land use pattern point of views, the layout or arrangement of the urban uses of the land in a Raipur city region at particular time and space is 
determined by the combinational interaction of socio-economic and natural factors through rapid growth of urban population. The socio-economic and technical organizational factors are interacting with one another over time and again for maintaining the continuation such process and the result of which is reflected on the urban land use pattern $(12,13)$.

Table 1: Showing the Distribution of Urban Land Use Categories of Raipur City, 2011

\begin{tabular}{|c|c|c|}
\hline \multirow{2}{*}{ Urban land use categories } & \multicolumn{2}{|c|}{ Areas of urban land use pattern } \\
\cline { 2 - 3 } & Areas in Hectares & Areas in Percentage \\
\hline Residential & 2050 & 55.3 \\
\hline Commercial & 180 & 4.8 \\
\hline Industrial & 430 & 11.6 \\
\hline Public and semi-public utilities & 450 & 12.1 \\
\hline Recreational & 100 & 2.7 \\
\hline Transportation & 500 & 13.5 \\
\hline Total & $\mathbf{3 7 1 0}$ & $\mathbf{1 0 0}$ \\
\hline
\end{tabular}

Source: Master Plan of Raipur city, 2011

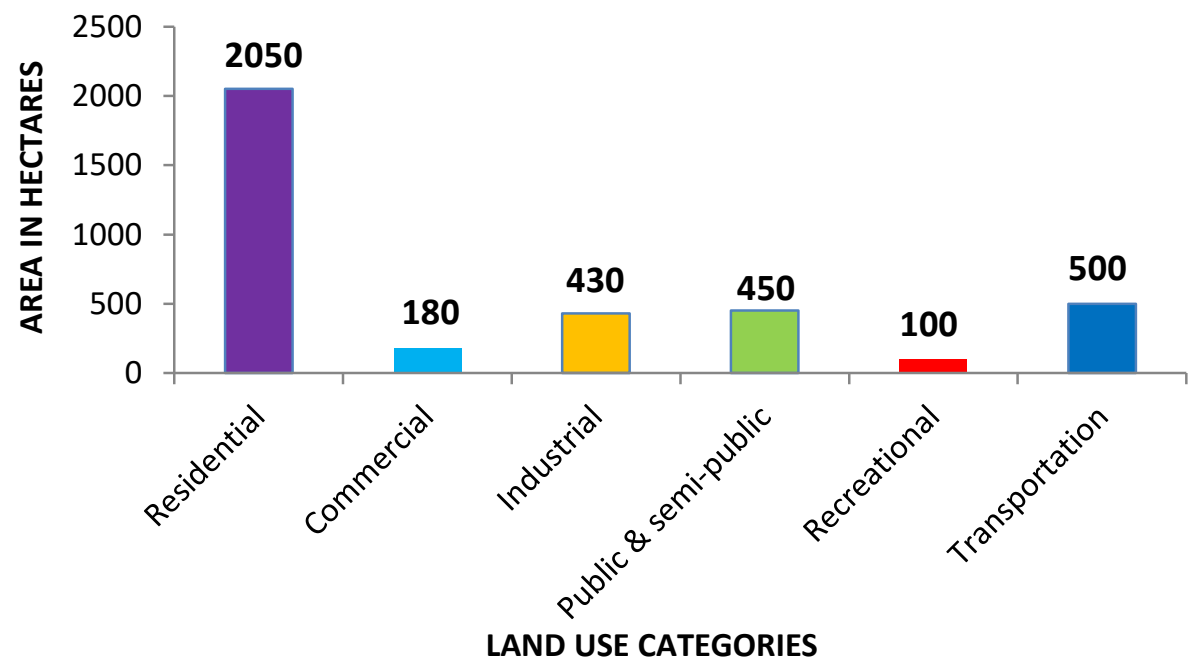

Figure 2: Showing the Urban Land Use Categories of Raipur City, 2011

Residential Area: The bulk of the built up area is devoted to residential use. The residential areas cover 2050 hectares which constitutes 55.3
$\%$ the developed area. The gross residential density works out to 370 persons per hectare. The core of the city is the purani basti which is now in 
a stage of gradual decay. Many new colonies have sprung up which are situated along the major roads. The community facilities in most of them are lacking. Another significant feature to note is the change in use of residential into some other uses particularly commercial use, abutting on the road. On the basis of field observation the mushroom growth of slums areas is remarkable concentrated in the surrounding (fringe area) of a city.
Commercial Area: In spite of the fact that Raipur is an important trade Centre, the city has no organized or planned commercial area. The main commercial Centre has developed on either side of malviya road, great eastern road and sadar bazar road. The total area devoted to commercial use is 180 hectares which constitutes $4.8 \%$ of the total developed area. The shops in other localities are situated along narrow lanes of the city.

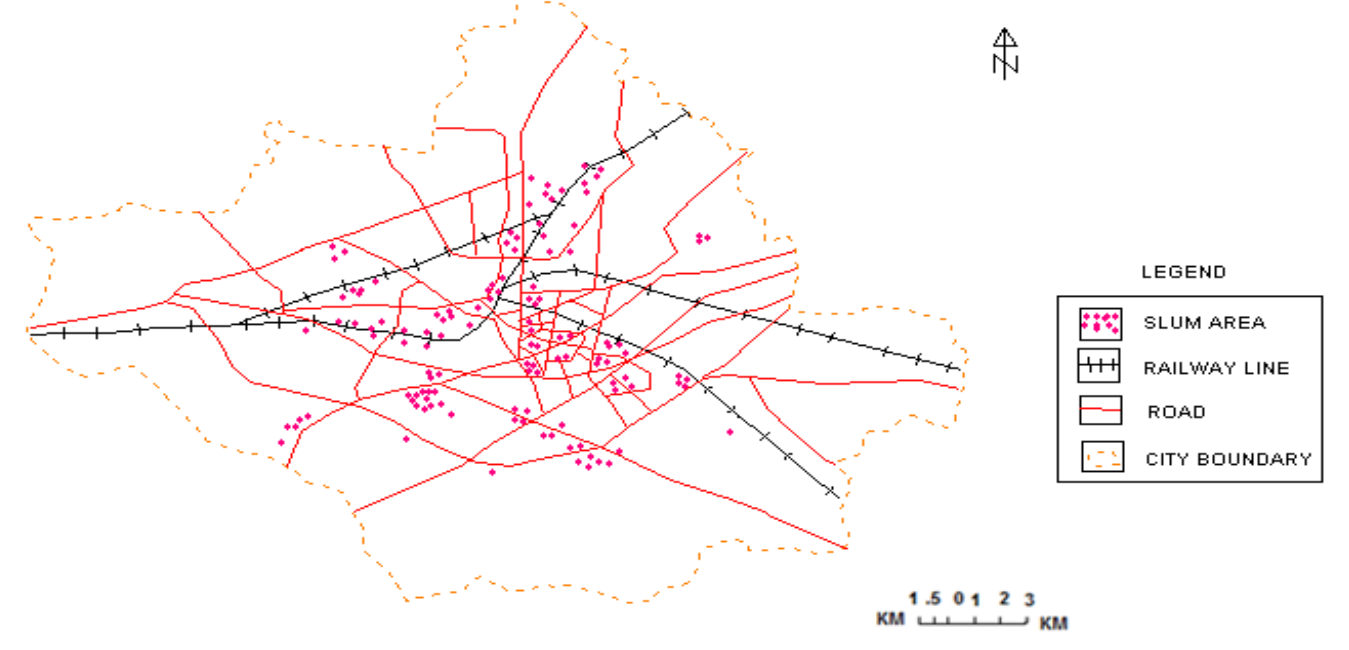

Figure 3: Showing the Slum Areas of Raipur City

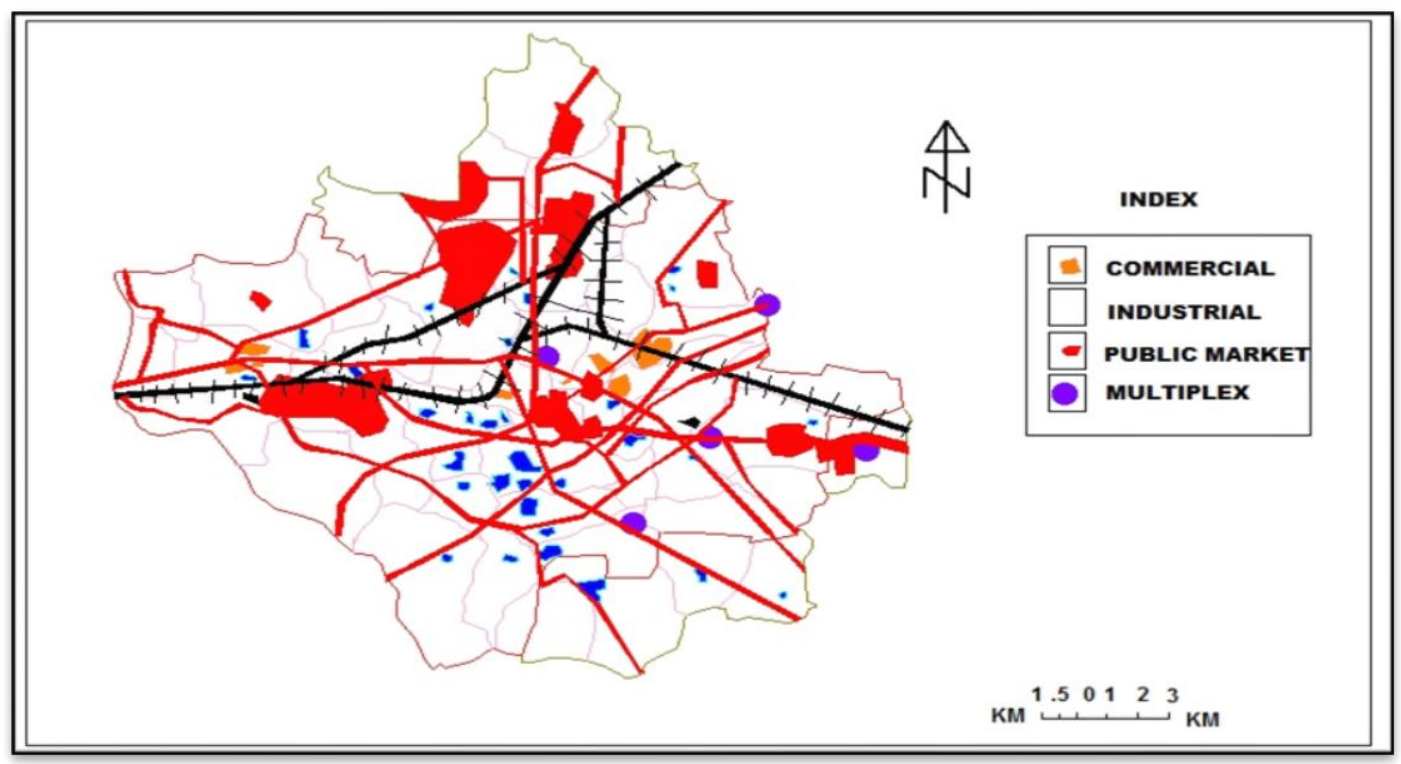

Figure 4: Work Centers of Raipur City 
Industrial Area: The total area under industrial use is 430 hectares (including wagon repair workshop and industrial estate) which forms $11.6 \%$ of the developed area. Some of the small scale industries are located in the heart of the city in residential and commercial areas. It is commonly found that there is a shop in the first room facing the road, living place in the central

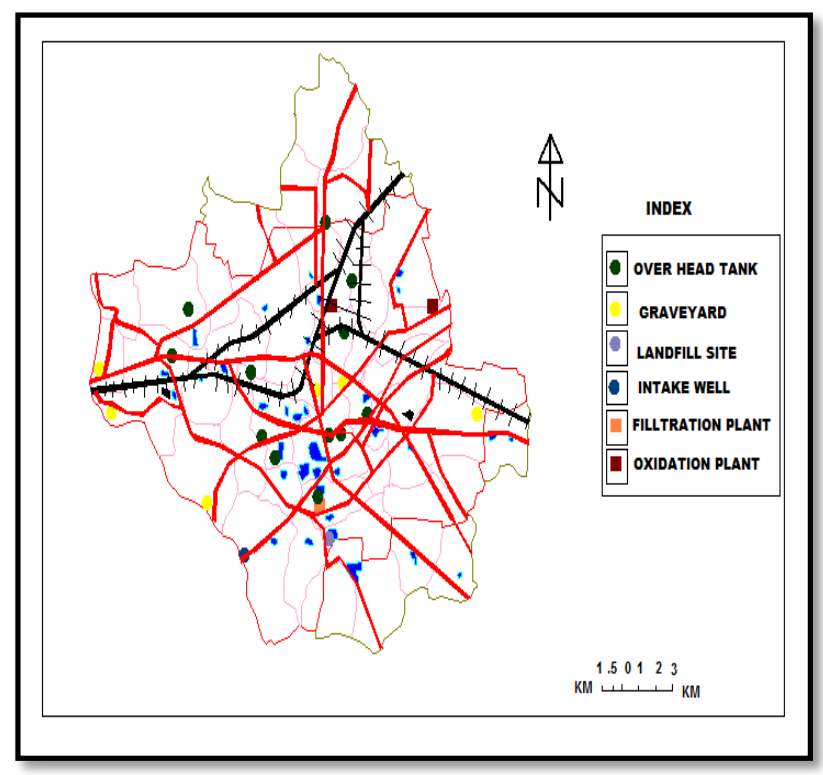

Figure 5: Public Utility and Facility of Raipur City

Recreational Area: The total area under recreational use works out to 100 hectares which is $2.7 \%$ of the developed area. The existing area under recreation is grossly inadequate for the city. All the parks except Moti Park and Gandhi Park are very small. As regards playgrounds, they are mostly attached to school and colleges. The present stadium is situated in an obscure corner of a Raipur city which is not properly linked with the city.

Transportation Area: In these categories of land use, the area under major city roads, railway yard, bus terminal, bus stand has been taken into account. It comprises an area of 500 hectares, 13.5 $\%$ of the development area. The road space has been encroached upon by abutting building, shops room and a small manufacturing unit in the rare of the buildings.

Public and semi-public Area: The public and semi-public institutions cover an area of 450 hectares which is $12.1 \%$ of the total developed area. This constitutes the area of all types of offices, education, health care, civic and cultural institutions etc.

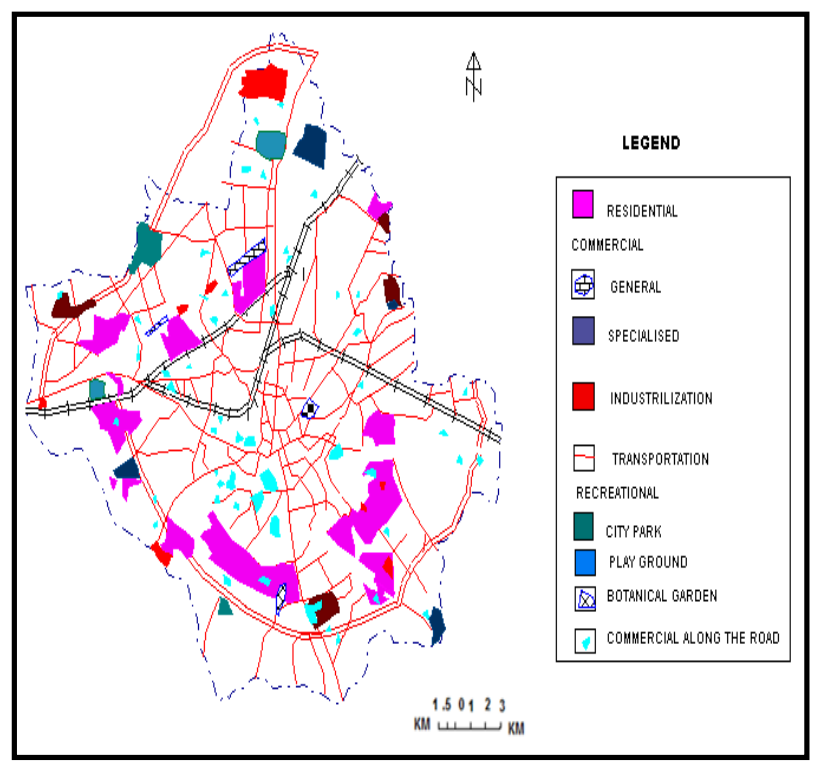

Figure 6: Scenarios of Urban Land Use Pattern in Raipur City, 2011

and temporary hutments which result in inadequate space for traffic movement.

\section{SCENARIOS OF EXISTING URBAN LAND USE PATTERN WITH REFERENCE TO PAST DECADE AS WELL AS PROPOSED URBAN LAND USE PLANS}

In the Master plan year 1976, the Residential area is $34.9 \%$ where existing residential area (2011) is $55.3 \%$ and the proposed residential area (2021) is $50.55 \%$ due to rapid growth of urban population as well as immigration. In the Master plan year 1976, Commercial area is $2.2 \%$ where existing commercial area 


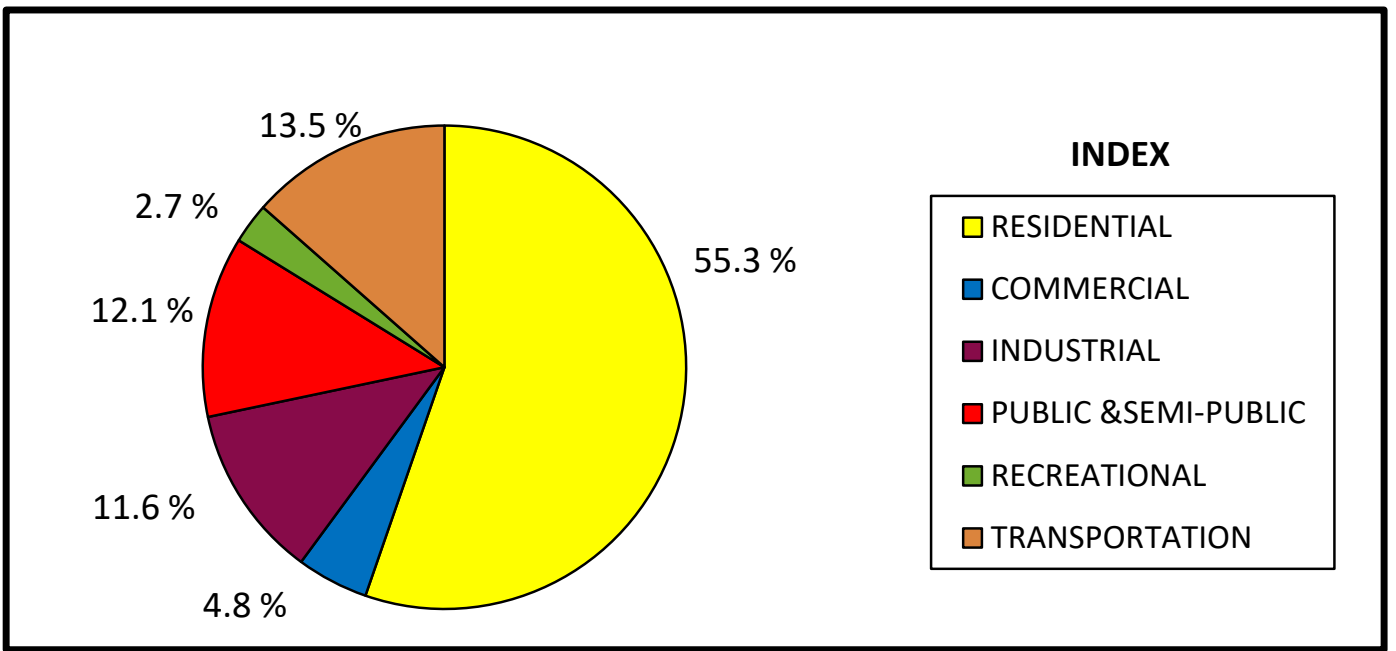

Figure 7: Percentage of Urban Land Use Categories in Raipur City, 2011

(2011) is $4.8 \%$ and the proposed commercial area (2021) is $8.56 \%$ due to the Raipur city becoming a capital city of Chhattisgarh state as well as important trade centre. In the Master plan year 1976 , Industrial area is $16.4 \%$ where existing industrial area (2011) is $11.6 \%$ and the proposed industrial area (2021) is $9.07 \%$ due to the shifting of industrial site towards fringe areas from the city centre. In the Master plan year 1976, Public \& semi-public area is $32.4 \%$ where existing Public $\&$ semi-public area (2011) is $12.1 \%$ and the proposed Public \& semi-public area (2021) is 9.41
$\%$ due to rapid growth of urban population. In the Master plan year 1976, Recreational area is 2.2 $\%$ where existing recreational area (2011) is 2.7 $\%$ and the proposed recreational area (2021) is $10.06 \%$ due to the development of several parks, playgrounds and stadiums. In the Master plan year 1976, Transportation area is $11.9 \%$ where existing transportation area (2011) is $13.5 \%$ and the proposed transportation area (2021) is 12.35 $\%$ due to the rapid growth of urban population as well as significant development of transport network system in the city.

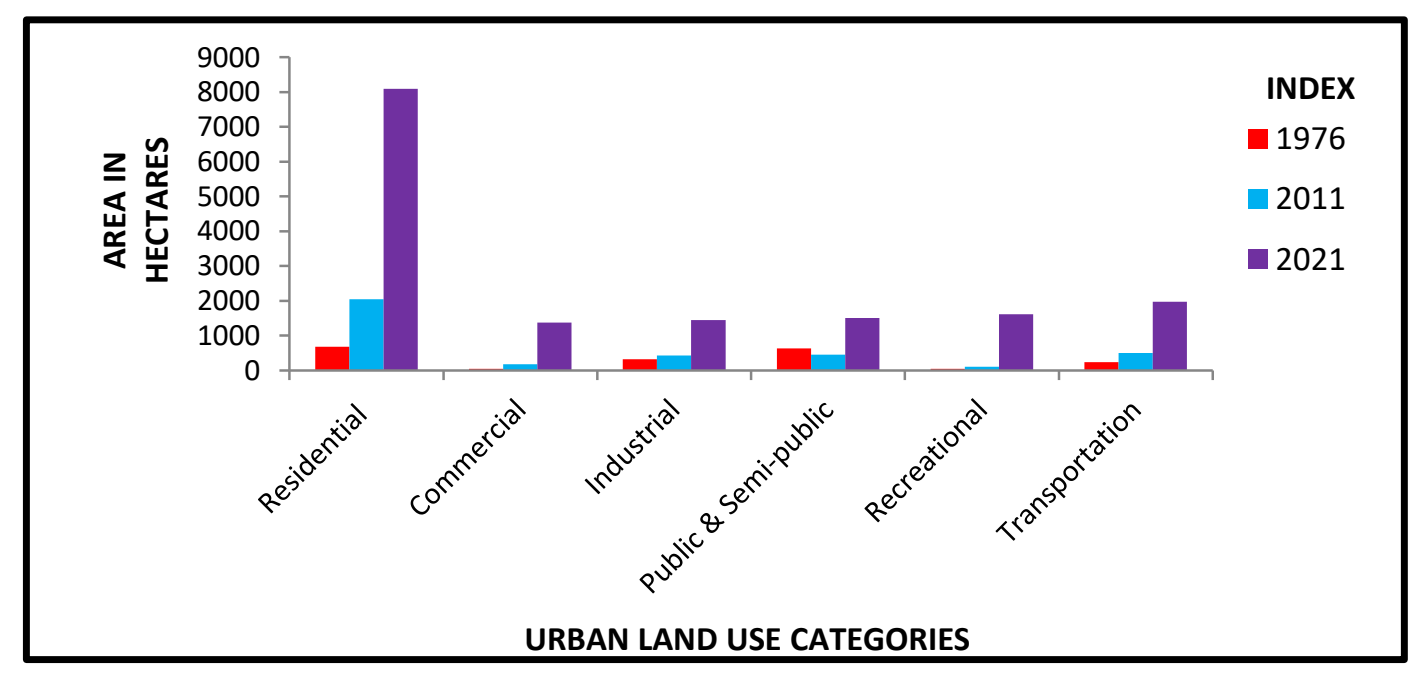

Figure 8: Showing the Scenarios of Existing Urban Land Use Pattern of Raipur City with Compare to Past Decade as well as Proposed Urban Land Use 


\section{PROBLEMS}

Urban land use as a main aspect of urban morphological studies in urban geography. The cities structures also deepen on this land use pattern with particular reference to optimum land utilization. A harmonious and well-co-ordinate development of various lands uses results in efficient functioning of a city. Raipur city face with several problems with particular reference to urban land use change.

(i) The disposition of various uses in Raipur city is the result of public and private decisions taken in isolated from time to time.

(ii) The various urban land use pattern are therefore, not well co-ordinate here.

(iii) Lack of pen spaces and other amenities.

(iv)There is no proper relationship between industrial units and residential colonies accommodating their workers.

(v) The industrial areas are far away on the fringe of the city on Bilaspur road while workers colonies are situated in the heart of the city.

(vi) In the context of urbanization, the city environments are polluted.

\section{SUGGESTIONS}

An attempt has been made throughout to preserve the character and heritage of the city and to weave a new pattern of growth for Raipur city which will fulfill the present as well as future requirement and also meet aspirations of its citizens.

(i) Adequate and suitable residential area for construction of houses.

(ii) An efficient and judicious use of land.

(iii) Well distributed work centres.

(iv) Utilization of existing capacities of the roads to its full extend.

(v) Retention of mixed land uses in central area.

(vi) Re-location of only incompatible and inefficient land uses to sustainable sites.

\section{CONCLUSION}

Urban Land use pattern in the Raipur city generally conforms to a regular and predictable pattern. Raipur city is an outcome of physical growth process and reflects man's efforts any achievements in shaping his environment during the entire period of its development. The social and cultural structures also influence upon the urban land use pattern. Urban land use pattern of Raipur city is determined by the combinational interaction of socio-economic and natural factors through rapid growth of urban population. Mushroom growth of slums areas is remarkable concentrated in the surrounding (fringe area) of a city. In Raipur city all four (Residential, Commercial, Recreational, Transportation) categories of urban land uses are proportionally increased day by day on present scenarios due to rapid growth of urban population. In Raipur city Industrial area is decreased due to the shifting of industrial site towards fringe areas from the city centre and public \& semi-public area is also decreased due to the lack of public \& semi-public centers in the city regions and not proper planning on public \& semi-public uses.

\section{ACKNOWLEDGEMENT}

We are sincerely our heartfelt gratitude to the members of town and country planning department and department of Municipal Corporation, Raipur (C.G.) for their kind helping hand and to provide the relevant information about the research work until the completion of this research paper and also express our deep sense of thankfulness to the members of Government and non-government institutions.

\section{CONFLICT OF INTEREST}

There is no conflict of interest in this present study. This research work is not a part of any other studies and it is our original work.

\section{REFERENCES}

1. Bhattacharya S, Basak T. The Morphology of Chittaranjan Township. Geographical Review of India, Geographical Society of India, Calcutta. 1970 Dec.; XXXII (4): 23-29.

2. Dubey KK. Urban Land Use - A Critical Review. The Indian Geographical Society, Madras-5. 1971 Jan. March; XIIV (1\&2): 45-51. 
3. Khan ZT. Bilaspur - A Study in Urban Geography. New Delhi, Northern book Center. 1994;

4. Chandramauli, Singh SB. Land Use Assessment and Management: A Case Study of Robertsganj Tehsil, Sonbhadra. National Geographical Journal of India. 2012 March; 58(1): 35-41.

5. Guha M. The Morphology of Calcutta. Geographical Review of India, Calcutta. 1953 September; XV (3): 1217.

6. Hazra S, Saradar J. Monitoring of Land use and Land cover -A Case Study of Nonagons Basin, North - 24 Parganas, West Bengal. Geographical Review of India. 2009 September; 71(3): 23-29.

7. Mishra AK, Sharma PR. Spatial Characteristics of Commercial Land use of Alwar City, Rajasthan. National Geographical Journal of India. 2009 December; 55(4): 112.
8. Kaushik SP, Kaur V. Urban Land use Analysis using GIS Technique: A Case Study of Karnal City. National Geographical Journal of India. 2009 June; 55(2): 33-46. 9. Pandey DK, Sharma VN. Land use Pattern in Saryupas Plain Uttar Pradesh: A Geographical Analysis. National Geographical Journal of India. 2012 December; 58 (4): 10. Singh MMP. The Impact of Urbanization of Land use in the Rural-Urban Fringe -A Case Study of Patna. The Indian Geographical Journal.1974; 3: 28-32.

11. Chopra N. Land use/Land Cover of a part of Sonbhadra District, U.P: A Geographical Analysis Using Remote Sensing Data. National Geographical Journal of India. 2011 Sept.; 57(3):12-19.

12. Gupta R. Pattern of Urban Land Use Changes in India. The Deccan Geographer. 2012 June;

50 (1): 115.

13. Singh BN, Singh V. Changes in Land use Pattern in Chakia Block, Chandauli District. National Geographical Journal of India. 2009 Dec.; 55(4): 35-46. 